\title{
Caminhos atlânticos \\ memória, patrimônio e representações da escravidão na Rota dos Escravos ${ }^{*}$
}

\section{Atlantic routes \\ memory, heritage and slave representations on the Slave Route ${ }^{* *}$}

\author{
Ana lucia araúso \\ Departamento de História, Howard University \\ Frederick Douglass Hall 2441 6th Street N.W. Room 302 \\ Washington D.C. United States, 20059 \\ analucia.araujo@gmail.com
}

RESUMO O artigo examina as diferentes representações da escravidão e do tráfico atlântico presentes na Rota dos Escravos da cidade de Ajudá, na atual República do Benim. Busca-se entender como estas representações exprimem e reconstroem diferentes memórias do passado escravista atlântico. Tenta-se mostrar que a Rota dos Escravos é um lugar construído, onde se percebem duas imagens do escravo, a da vítima absoluta e a do resistente. O percurso proposto sugere dois níveis de leitura: de um lado, os monumentos constituem uma encenação, cujo objetivo é emocionar os descendentes da diáspora (principalmente os norteamericanos), que têm recursos financeiros para fazer turismo em países estrangeiros; de outro lado, as estátuas concebidas pelo artista Cyprien Tokoudagaba e os templos existentes na Rota dos Escravos posicionam o visitante no cruzamento de diferentes memórias e diferentes histórias da escravidão, onde

\footnotetext{
* Artigo recebido em: 07/10/2008. Autor convidado.

** A pesquisa realizada para a redação desse artigo foi possível graças ao New Faculty Start-Up Program da Howard University.
} 
a vitimização dá lugar à afirmação cultural que valoriza a arte, as religiões e as culturas africanas.

Palavras-chave memória, patrimônio, escravidão, vodu

ABSTRACT This paper examines the different representations of slavery and the slave trade found on the Slaves Route in Ouidah, present Republic of Benin. It aims at understanding how these representations express and reconstruct different memories of the Atlantic slave past. The paper shows that Ouidah's Slaves Route is a constructed space, where we can find two different images of enslaved Africans: the absolute victim and the resister. The proposed itinerary suggests two levels of interpretation: on the one hand, the monuments staging the past aim at emotionally move the diaspora (especially African Americans) who have the financial resources to travel abroad; on the other hand, the statues conceived by Cyprien Tokoudagaba and the existing vodun temples on the Slaves Route place the visitor at the crossing position between different memories and different histories of slavery, where victimization is replaced by cultural assertion, through the promotion of African art, religions, and cultures.

Keywords memory, heritage, slavery, vodu

Este artigo busca compreender as diferentes representações da escravidão e do tráfico atlântico presentes na Rota dos Escravos da cidade de Ajudá situada no litoral ocidental da atual República do Benim. Conhecida como Ajudá pelos portugueses, a cidade atual de Ouidah era também designada pelos locais como Glehue ou Gléxwé. ${ }^{1}$ No presente texto preferimos utilizar "Ajudá", nome português do reino que acabou por designar a cidade costeira. ${ }^{2}$

Nós tentamos entender como estas representações exprimem e reconstroem diferentes memórias do passado escravista. Em grande parte baseadas nas ilustrações dos relatos de viagem europeus dos séculos XVIII e XIX, estas imagens bidimensionais ou tridimensionais sugerem a recorrência de certos elementos formais e temáticos: as correntes e cordas atadas ou arrebentadas, a posição do corpo dos indivíduos, às vezes encurvados, de joelhos ou ainda agachados, assim como as noções de

Nome em língua fon.

2 Cabe, porém, lembrar que a capital do reino de Ajudá, se chamava Savi (ou ainda Sahe, Savier ou Xavier). Dependendo da língua e da época, podem-se encontrar diversos nomes para designar o reino, tais como Huedá, Xweda, e Whydah, tanto para designar a cidade como o reino que ali se encontrava. Ver COSTA e SILVA, A. Francisco Félix de Souza, mercador de escravos. Rio de Janeiro: Nova Fronteira, 2004, p.12. 
sequência e repetição. Tendo como ponto de partida estas representações, nós buscamos mostrar que a Rota dos Escravos é um lugar construído, que coloca em cena o passado, valorizando certos aspectos em detrimento de outros. No labirinto do percurso sugerido, a valorização de duas imagens distintas do escravo, a vítima absoluta e o resistente, não desmerece, no entanto, as figuras do algoz. Esse personagem encarnava-se nas figuras do mercador de escravos, do membro da realeza do reino do Daomé ou, ainda, nas amazonas do exército do Daomé, que participavam ativamente das guerras produtoras de cativos, em grande parte destinados ao comércio transatlântico.

A análise do conjunto de monumentos erigidos no espaço público da cidade de Ajudá durante os últimos quinze anos, no quadro dos projetos A Rota do Escravo e Ajudá 92, nos faz questionar o uso das noções de memória, patrimônio e patrimonialização, quando se trata de examinar o contexto africano. Mesmo que um estudo comparativo entre Ajudá e outras cidades beninenses, como Cotonou, Porto Novo, Abomey e Ketu, pudesse ser frutífero, o espaço desse artigo não nos permite tal prolongamento. A escolha da cidade de Ajudá também se justifica pelo fato de que se trata, depois de Angola, do segundo porto escravagista africano mais importante durante o período do comércio atlântico. Durante a década de 1990, a cidade também foi o palco de vários projetos oficiais visando à valorização da memória da escravidão na região. A realização de projetos de promoção da memória da escravidão e da religião vodu ajudou a recolocar em evidência a cidade de Ajudá no cenário nacional e mesmo internacional.

No início dos anos noventa, vários organismos oficiais, como a UNESCO, o governo do país e os membros da elite beninense juntaram esforços para dar início a uma dinâmica voluntária ou involuntária de patrimonialização da escravidão e do tráfico atlântico. Essa onda patrimonial foi caracterizada não somente pela valorização dos patrimônios material e imaterial da escravidão, mas, também, pela construção de um grande número de monumentos e pela criação de vários museus familiares. Ao estabelecer relações entre os discursos visíveis nos monumentos, memoriais e museus e aqueles desenvolvidos de um lado pelos atores locais e de outro lado pelos organismos oficiais, percebe-se a complexidade das memórias da escravidão, que, nesse contexto, apresentam vários elementos conflituosos.

No furor do processo de patrimonialização do passado escravista, cabe lembrar que a memória da escravidão não é unicamente ligada àqueles que sofreram os efeitos do cativeiro, da deportação, dos castigos corporais e dos trabalhos forçados. Essa memória também é reconstruída por aqueles que participaram e colaboraram com o tráfico atlântico: comerciantes de escravos, intérpretes, capitães de navios e mestres. Dessa maneira, é impossível falar de uma única memória da escravidão, mas, sobretudo, de memórias plurais, que podem, eventualmente, ser convergentes. Mas, na 
maior parte dos casos, trata-se de memórias conflituosas. Essas dissonâncias se traduzem no espaço público beninense, dividido por disputas memoriais. A memória da escravidão também está longe de ser unicamente ligada ao passado do país. Ela renova no tempo presente as disputas políticas entre os diversos grupos que buscam obter uma melhor posição social, seja ela econômica ou simbólica, entre os membros da comunidade local e da diáspora.

No Benim, mesmo se uma certa memória da escravidão é presente nos discursos dos descendentes de escravos retornados ou ainda daqueles indivíduos que foram escravizados no próprio continente africano e, também, entre os descendentes dos mercadores de escravos e de outros atores que colaboraram na organização do tráfico, esses grupos não viveram diretamente a experiência de seus ancestrais. Hoje em dia, estudar a memória da escravidão significa trabalhar na ausência da figura da testemunha, aquela que viveu a experiência dos fatos narrados. Como lembra Marianne Hirsch, este tipo de memória que se manifesta em outras gerações, assim como em diferentes formas de criação artística contemporâneas pode ser qualificada de pós-memória. Essa modalidade da memória evocada por Hirsch é característica entre aqueles que cresceram dominados pelas histórias de eventos traumáticos passados, vividos por seus ancestrais, ${ }^{3}$ lembranças esparsas de outras gerações, como aquelas que nos relatou Saidyia Hartman na narração do seu retorno à antiga Costa do Ouro. ${ }^{4}$

Os projetos A Rota do Escravo e Ajudá 92 visavam promover o turismo cultural na região. O desenvolvimento desse tipo de atividade econômica ajudaria eventualmente a aumentar a atividade econômica da cidade, antigo porto escravagista, que desde o final do século XIX, com o final do comércio de escravos e o início da colonização francesa, se encontrava em franco declínio. A criação de museus, a organização de festivais e a construção de monumentos situados no espaço urbano constituíram a expressão das memórias públicas oficiais da escravidão. Estas memórias, que aqui não se situam mais no terreno da transmissão, mas no da reconstrução, são, em grande parte, tributárias das gerações que cresceram em um lugar marcado pelo legado do tráfico atlântico de africanos escravizados. Nesse contexto, a Rota dos Escravos da cidade de Ajudá é um lugar de memória, onde as testemunhas estão ausentes, se constituindo assim como um sítio de pósmemória, ${ }^{5}$ ou seja, um local de reexperimentação, de reinterpretação e de reinvenção do passado. Para participar dessa encenação, baseada em múltiplas representações da escravidão e dos africanos escravizados, os

$3 \mathrm{HIRSCH}$, M. Family frames, photography narrative and postmemory. Cambridge: Harvard University Press, 1997, p.22.

4 HARTMAN S. Lose your mother: a journey along the Atlantic Slave Route. New York: Farrar, Straus and Giroux, 2007

$5 \mathrm{HIRSCH}, \mathrm{M}$. Family frames, photography narrative and postmemory, p.22. 
turistas e visitantes são chamados a se deslocar em um espaço que permite várias interpretações das experiências passadas, supostamente vividas ali. Esse percurso, que orienta o visitante, mas que continua aberto, "permite não permanecer fascinado, alucinado, mas fazer parte da consciência do afastamento". ${ }^{6}$

\section{Revisitando a história do reino do Daomé}

A expansão territorial do reino do Daomé se deu a partir do século XVIII e foi o resultado de campanhas militares bem sucedidas contra os estados vizinhos. Durante essas guerras, grande parte dos prisioneiros capturados era vendida como escravos aos mercadores europeus e americanos estabelecidos na costa. Com o fim do tráfico atlântico, as potências européias se encontram em situação vantajosa para ocupar e colonizar diferentes partes do território africano. No final do século XIX, a França conquistou o Daomé, enviando o rei Behanzin para o exílio na Martinica, estabelecendo no antigo reino a colônia do Daomé.

O Daomé tornou-se independente em 1960 e, depois dessa data, quatro golpes de Estado tiveram lugar no país. Em 1972, o general Mathieu Kérékou tomou o comando do país, instaurando uma ditadura marxista-leninista, período que ficou conhecido como "Revolução". A partir de novembro de 1975, o presidente decidiu mudar o nome do país para República Popular do Benim. Essa mudança de denominação ${ }^{7}$ visava romper não somente com o passado associado ao comércio atlântico de escravos, mas também com a escravidão em terras africanas. Ao menos em teoria, apagar os traços desse passado permitiria construir um novo futuro, no qual os antigos oprimidos poderiam finalmente ter uma voz. No entanto, na realidade, as coisas se passaram de outra maneira. Durante o período da Revolução, criou-se um forte aparelho repressivo; não só a liberdade de expressão foi tolhida, mas também a liberdade de culto religioso.

Se a maioria da população, adepta das religiões ditas "tradicionais", como o vodu, continuou praticando-as, as atividades ligadas ao culto passaram a ter lugar exclusivamente dentro do espaço doméstico e não no espaço público. Em 1989, seguindo a queda do muro de Berlim, uma onda de greves paralisou o país e os abusos da ditadura do general Kérékou passaram a ser denunciados. Países credores como a França, a República Federal da Alemanha ou ainda o Banco Mundial e o Fundo Monetário Internacional deram seu apoio ao movimento pela democracia. No final de 1989, o governo se viu obrigado a fazer importantes concessões aos

6 ROBIN, R. La memoire saturée. Paris: Stock, 2003, p.323.

7 KEREKOU, M. Dans la voie de l'édification du socialisme. In: Recueil des discours de notre grand camarade de lutte le président Kerekou. République Populaire du Bénin: Éditions Graphic Africa, 1979, p.21. 
movimentos populares e se comprometeu a abandonar o "marxismo-leninismo", a separar o Partido da Revolução Popular do Benim do Estado, a abolir o partido único, instaurando o pluripartidarismo, e a convocar um fórum nacional para discutir a crise.

Em 1990, após vários meses de manifestações populares e conflitos, as pressões exercidas pela oposição resultaram na convocação, pelo presidente Kérékou, de uma conferência nacional, cujo objetivo era fazer a transição para a democracia. A mudança foi favorecida pela queda da União Soviética e dos regimes comunistas dos países da Europa do Leste. Nicéphore Soglo foi nomeado primeiro-ministro interino e, em 1991, foi eleito presidente. O novo chefe de Estado queria o desenvolvimento de um novo Plano Marshall "para redefinir de maneira mais explícita as condições de financiamento dos programas de ajustamento estrutural e de reembolso da dívida de nossos Estados". ${ }^{8}$ A ideia de desenvolver um Plano Marshal tinha como objetivo principal renegociar ou mesmo anular a dívida dos países africanos. Mesmo se Soglo não formulou nenhum pedido formal de reparação, a ideia do Plano não se diferenciava muito dos primeiros pedidos formais de reparações pelos séculos de tráfico atlântico de escravos e de colonização reivindicados pela União Africana na mesma época. Foi nesse período que o Benim começou a recorrer à ajuda do Banco Mundial e do Fundo Monetário Internacional. Assim, o turismo cultural tornou-se uma das alternativas viáveis, tendo em vista promover o desenvolvimento econômico do país.

\section{Patrimônio e turismo}

A valorização dos sítios ligados ao tráfico atlântico de escravos no Benim remonta ao período posterior à Segunda Guerra Mundial. Pierre Verger, com a ajuda do IRAD, ${ }^{9}$ da França e da República Federal da Alemanha, incentivou e promoveu a restauração do antigo forte português de São João Batista da Ajuda. Em 1967, o forte se tornou o Museu de História de Ajuda. ${ }^{10}$ O museu passou a ocupar a superfície de 1 hectare, que inclui um grande edifício, onde ficava a residência dos antigos oficiais portugueses, no qual se encontram hoje o acervo da instituição. O sítio contém ainda uma capela, uma antiga guarnição e as casernas. Em 1943, a administração colonial já tinha tomado a decisão de estabelecer o Museu Histórico de Abomé ${ }^{11}$ nos antigos palácios reais de Abomé. A área total do sítio totaliza 44 hectares. Os palácios dos reis Guezo e Glèlè, onde as coleções do museu são ex-

\footnotetext{
8 SOGLO, N. L'allocution du Président Soglo au 28e Sommet de l'O.U.A. à Dakar. La Nation, Cotonou, p.5, 13 juillet 1992.

9 Instituto de Pesquisas Aplicadas do Dahomey.

$10 \mathrm{http}: / /$ www.museeouidah.org/

11 http://www.epa-prema.net/abomey/
} 
postas, ocupam aproximadamente 2 hectares. Em 1985, após terem sido danificados durante um furacão, os palácios foram colocados, ao mesmo tempo, nas listas da UNESCO do patrimônio mundial e do patrimônio mundial em perigo. ${ }^{12}$

Os palácios foram incluídos nas duas listas da UNESCO porque eles correspondiam a dois critérios básicos estabelecidos pela organização: de um lado, eles trazem "um testemunho único ou pelo menos excepcional de uma tradição cultural viva ou desaparecida" e, de outro lado, eles oferecem um "exemplo eminente de um tipo de construção ou de conjunto arquitetural ou tecnológico ou de paisagem ilustrando um ou vários períodos significativo(s) da história humana". ${ }^{13}$

O projeto de restauração e conservação dos palácios reais, que fazia parte do programa de Prevenção nos Museus da África (PREMA), foi realizado em parceria com o governo do Benim. A primeira fase do projeto começou em 1992, graças ao financiamento vindo de diferentes organismos, como a Cooperação Alemã, o Instituto Getty de Conservação e a Agência de Cooperação Cultural e Técnica (ACCT), atual Organização Internacional da Francofonia. Durante essa primeira etapa, as coleções foram recuperadas e organizadas em uma nova reserva. Entre 1995 e 1997, ao longo da segunda e terceira etapas, financiadas pelo fundo da Cooperação Italiana da UNESCO, foram encontrados 56 baixos-relevos que ornamentavam as paredes do antigo palácio do rei Glèlè. $O$ trabalho dos restauradores consistiu em reunir a documentação sobre a arquitetura do sítio, treinar os restauradores e publicar os documentos de referência e em organizar um colóquio tendo como assunto os palácios reais.

Os baixos-relevos coloridos que decoram as paredes do palácio formam uma história constituída por imagens, representando diferentes dinastias abomeanas. As representações dos guerreiros e guerreiras armados e dos prisioneiros decapitados descrevem claramente as campanhas militares do reino do Daomé contra os reinos vizinhos. No começo, pode-se afirmar que a restauração dos edifícios históricos se enquadrava numa perspectiva de valorização da memória do reino do Daomé e não necessariamente numa dinâmica de recuperação da memória da escravidão. No entanto, como na mesma época outros projetos ligados à memória da escravidão foram desenvolvidos no Benim, a restauração dos palácios teve o efeito de reavivar a memória da escravidão, não necessariamente do ponto de vista dos grupos escravizados, mas daqueles que participaram ativamente na produção e no comércio de escravos.

12 Segundo a Decisão 29 COM 7A.13 de 1985.

13 La liste: les critères de sélection. In: Patrimoine mondial. UNESCO : http://whc.unesco.org/fr/criteres/ 


\section{Patrimonializando a escravidão}

No começo dos anos 1990, durante o processo de redemocratização, a República do Benim passou a mostrar ao mundo aspectos de sua história e de suas culturas. Dentro dessas especificidades, se encontra o comércio atlântico de africanos escravizados, pois o atual país se encontra no âmago do que foi no passado o reino do Daomé, um dos maiores reinos escravagistas da África Ocidental. Foi durante os preparativos das comemorações dos 500 anos da chegada de Cristóvão Colombo às Américas que os representantes do Haiti chamaram a atenção para o fato de que pouca atenção tinha sido dada ao papel dos africanos na construção do Novo Mundo. A delegação haitiana lançou a ideia de desenvolver um projeto científico para preencher essa lacuna, que foi batizado com o título de Rota do Escravo. A discussão sobre a memória da escravidão no contexto local e, também, numa perspectiva mais abrangente não se mostrou uma tarefa simples. No começo, os idealizadores do projeto se propunham a discutir não somente o papel dos países europeus no comércio atlântico de escravos, mas, também, a lembrar a responsabilidade dos países africanos e muçulmanos no tráfico interno e no tráfico trans-saariano. Apesar disso, o projeto acabou sendo articulado somente em torno do comércio atlântico e foi dividido em cinco eixos: científico, educacional, artístico e cultural, conservação de arquivos e turismo cultural.

Quase na mesma época do começo da discussão sobre o lançamento do projeto Rota do Escravo, colocou-se uma outra iniciativa sobre a mesa, o projeto do $1^{\circ}$ Festival mundial das culturas vodu: reencontros Américas-Áfricas: Ajudá 92. ${ }^{14} \mathrm{O}$ festival seria não somente uma ocasião de comemorar o vodu do reino do Daomé, ${ }^{15}$ mas, também, as religiões americanas herdadas da escravidão, entre as quais o vodu haitiano e o candomblé brasileiro. $\mathrm{Na}$ época, os objetivos, ao mesmo tempo convergentes e conflitantes dos dois projetos, foram objeto de debate nos jornais do país, entre os membros do governo e os chefes locais. ${ }^{16}$

Devido a seu programa inclusivo, o festival Ajudá 92 obteve mais destaque que o projeto A Rota do Escravo e ocorreu em fevereiro de 1993. O momento da realização do festival foi bem escolhido, pois o país acabava de sair de uma ditadura, período durante o qual o vodu estava banido do espaço

14 O nome original em francês (língua oficial do país) foi $1^{\text {er }}$ Festival mondial des cultures vaudou: rencontres Ameriques-Afrique: Ouidah 92.

15 A definição de vodu utilizada aqui é aquela sugerida por Susan Preston Blier: "forças ou poderes misteriosos que governam o mundo e as vidas daqueles que nele residem". BLIER, S. P. African Vodu: art, psychology, and power. Chicago: Chicago University Press, 1995, p.4.

16 TALL, E. K. De la Démocratie et des cultes vodus au Benin. Cahiers d'études africaines, v.137, p.195-208, 1995 e BAKO-ARIFARI, N. La Mémoire de la traite négrière dans le débat politique au Bénin dans les années 1990. Journal des Africanistes, v.70, ns.1-2, p.221-231, 2000. Sobre as repercussões dos debates nos jornais locais, ver BINAZON, R. "La Guerre des vodounons" au Bénin: quelles conséquences pour les manifestations de "Ouidah 92" e la "Route de l'esclave" ? La Nation, Cotonou, p.3, 1992. 
público. A iniciativa foi apoiada e patrocinada por vários chefes de Estado africanos, instituições e personalidades do mundo cultural e artístico. ${ }^{17}$ Várias manifestações, entre as quais concertos, uma feira do livro e um festival de cinema vodu, tiveram lugar nas cidades de Ajudá, Porto Novo e Cotonou. Em Ajudá, quatro sítios foram organizados: a Casa do Brasil, a Floresta Sagrada, a Casa de Daagbo Hounon, chefe supremo do vodu em Ajudá e a Rota dos escravos, sobre o qual concentraremos nossa atenção nesse artigo.

\section{Construindo a Rota dos Escravos}

A Rota dos Escravos é uma estrada de chão batido que parte do centro da cidade, onde estava situado o mercado de escravos, indo até a praia, onde os cativos eram supostamente embarcados. Nessa estrada foram colocadas uma centena de estátuas de cimento, concebidas pelos artistas beninenses Cyprien Tokoudagba e Dominique Kouas. A maior parte das esculturas evoca vodus associados às forças da natureza, como Heviosso e Mammi Wata, mas principalmente os símbolos dos reis do Daomé, que se tornaram divindades do vodu. Outras esculturas representam igualmente os cativos enviados como escravos às Américas. Os lugares onde as esculturas e memoriais foram instalados, pontuam as diferentes etapas do caminho. Os templos do vodu já existentes na Rota foram decorados com pinturas realizados por diferentes artistas vindos da Nigéria, do Togo, do Haiti e do Brasil. O número de convidados estrangeiros, o apoio financeiro do governo de outros países e o panfleto do programa traduzido em inglês não deixam dúvidas de que o festival foi concebido como um lugar de encontro da diáspora africana.

A escolha do artista abomeano Cyprien Tokoudagba não se deu por acaso. Iniciado ainda jovem à religião vodu, ele começou sua carreira pintando afrescos ilustrando temas ligados ao vodu nas paredes dos templos. Em seus primeiros trabalhos, Tokoudagba utilizava a argila e mais tarde ele passa a empregar o cimento e a areia. Tokoudagba foi então aconselhado a transpor os motivos pintados nos afrescos para as telas, que poderiam ser comercializadas no mercado estrangeiro. Em 1987, ele começou a trabalhar como restaurador de esculturas e baixos-relevos no Museu Histórico de Abomé e foi a partir dessa época que sua produção começou a ser notada. Em 1989, o artista viajou para o exterior pela primeira vez, para participar da exposição coletiva Les magiciens de la terre (Os mágicos da Terra), que teve lugar no Centro Pompidou, em Paris. A mostra marcou uma nova fase nas exposições europeias de arte contemporânea, pois, pela primeira vez, a crítica internacional deu um lugar de honra às obras de artistas não-oci-

17 Principalmente no jornal La Nation e La Croix. A maior parte dos jornais beninenses existentes atualmente, entre os quais L'Autre, Le Matin e Le Matinal foram criados em meados de 1994. 
dentais. Consagrado na França, durante os anos seguintes, Tokoudagba mostrou seus trabalhos em várias exposições coletivas e individuais internacionais, entre as quais a Bienal de São Paulo. Assim, o fato que o seu nome tenha sido escolhido para realizar a maior parte dos monumentos do festival Ajudá 92 foi motivado, de um lado, por sua reputação como artista e, de outro lado, pelo vodu já ser um tema privilegiado na sua obra.

Para o visitante iniciado, a associação entre o vodu e o comércio atlântico de escravos é visível em toda a extensão do percurso. A Rota atravessa vários bairros, colocando em evidência sítios históricos e, também, os templos do vodu já existentes. Considerando que durante os séculos XVIII e XIX outros caminhos também conduziam até a praia e que uma parte do trajeto realizado pelos escravos não era feito a pé, mas dentro de canoas, devido à existência de uma rede lagoas, a Rota dos Escravos pode ser considerada como um percurso fictício. Se vários monumentos foram instalados nos lugares ocupados por sítios históricos, diferentes memoriais e estátuas foram colocados ao longo do caminho apenas para reforçar a ideia de continuidade, sem necessariamente marcar um evento ou um ponto de referência em particular: a verossimilhança do discurso histórico é bem menos importante do que a encenação da memória do tráfico atlântico de africanos escravizados. ${ }^{18}$

\section{Escravidão e religião vodu}

A Rota dos Escravos apresenta diversas imagens da escravidão: aquelas que evocam claramente a figura do escravo e aquelas que fazem alusão à escravidão por intermédio das divindades do vodu ou ainda pelas referências ao reino do Daomé. O primeiro ponto da Rota dos Escravos é a Place des enchères ou Praça Chacha. Esta praça fica localizada atrás da antiga residência de Francisco Félix de Souza, mercador de escravos brasileiro, estabelecido no Golfo do Benim desde o começo do século XIX. Na época, o rei Adandozan e Félix de Souza tiveram um desentendimento motivado provavelmente por uma dívida ligada ao comércio de escravos. O mercador foi, então, enviado para a prisão, onde entrou em contato com o príncipe Gakpe, que seria meio-irmão de Adandozan. Os dois, então, fizeram um pacto de sangue e o mercador brasileiro ajudou o príncipe a organizar um golpe de Estado. Gakpe tornou-se rei Guezo e para recompensar Francisco Félix de Souza pela ajuda prestada Ihe concedeu terras e também o nomeou para a função de intermediário comercial do rei nos assuntos ligados à exportação de escravos em Ajudá. O apelido "Chacha", ${ }^{19}$ que já

18 RUSH, D. Contemporary Vodu Arts of Ouidah, Benin. African Arts, v.34, p.32-47, 2001

19 Entre os autores que discutiram a origem do apelido, podemos citar DUNGLAS, E. Le Chacha F. F. de Souza. France-Dahomey, maio-junho, 1949 e COSTA E SILVA, A. Francisco Félix de Souza, mercador de escravos. 
acompanhava o mercador brasileiro, tornou-se um título, agora indicando seu papel de intermediário do rei, função esta que foi confundida por muitos autores com aquela de "vice-rei". ${ }^{20}$

A Praça Chacha se situa no lugar onde as vendas de cativos tinham lugar na época do tráfico atlântico. Porém, a estátua de cimento, concebida por Tokoudagba, que foi instalada na praça, não se refere diretamente ao mercador brasileiro, mas, sobretudo, ao seu parceiro, o rei Guezo. A estátua representa uma amazona do exército do Daomé, uma mulher guerreira, com os seios nus e portando um par de cornos. ${ }^{21} \mathrm{Na}$ base da escultura, encontra-se a legenda do festival Ajudá 92 e o nome da praça, mas a menção às amazonas é ausente. Insiste-se, sobretudo, na autenticidade do sítio: "é sob esta árvore e nesse lugar que aconteciam as vendas públicas durante as quais os escravos destinados às Américas eram trocados por mercadorias de pacotilhas". Em 1993, quando a estátua foi inaugurada, a antiga residência de Francisco Félix de Souza estava praticamente abandonada. Em 1995, depois da entronização de Honoré Félicien Julião de Souza, como Chacha VIII, foi que o novo representante da família decidiu renovar a antiga casa de seu ancestral e, também, construir um novo "palácio" de quatro andares no mesmo local onde a antiga construção ficava situada no passado. Em 1999, seis anos após a realização do festival Ajudá 92 e quatro anos depois da entronização do Chacha VIII, uma placa comemorativa foi acrescentada perto da estátua representando a amazona, indicando que naquele lugar se encontrava a Praça Chacha. Segundo o texto gravado nessa placa, a reabilitação da praça foi financiada pela República Federal da Alemanha, que já havia participado da restauração dos palácios reais de Abomé. Hoje, os visitantes e os turistas estrangeiros se deslocam para visitar e conhecer a casa do mercador de escravos brasileiro. Como o ponto de partida da Rota é, de fato, a Praça Chacha, fica impossível negar que o festival vodu teve um impacto positivo na promoção da memória de Francisco Félix de Souza e, também, do novo "palácio" da família, que, embora continuasse inacabado em 2005, foi inaugurado no ano seguinte, durante uma visita oficial do Presidente do Brasil, Luís Inácio Lula da Silva, à Ajudá.

As diferentes estátuas situadas na Rota dos Escravos constituem um tipo de catálogo das divindades do vodu. Elas representam as divindades situadas na mais alta hierarquia do panteão vodu, como aquelas associadas às forças da natureza, como o ar, a água, o fogo e a terra. A maior parte das esculturas monumentais faz parte da iconografia tradicional associada aos

20 O título de vice-rei foi questionado por Robin Law, que considera que a função de vice-rei ou chefe dos brancos (yovogan) sempre foi ocupada por um nativo e que o papel do mercador brasileiro era sobretudo o de um cabeceira, ver LAW, R. Ouidah: the social history of a West African slaving "port", 1727-1892. Athens: Ohio University Press, 2004, p.168.

21 HERKOVITS, M. Dahomey: an ancient West African kingdom. Evanston: Northwestern University Press, 1967, vol.2, p.46. 
vodus da família real do Daomé e algumas se inscrevem na tradição artística bocio. Nesta tradição, as esculturas figurativas são objetos de poder, que, adquirindo uma forma antropomórfica, ativam as divindades, claramente visualizadas no objeto. ${ }^{22}$ No entanto, se estas imagens são normalmente restritas ao espaço privado, aqui elas se encontram na esfera pública. Mesmo se as esculturas de Cyprien Tokoudgaba e Dominique Kouas visem a um público internacional, principalmente os pertencentes à diáspora africana, não se encontra na base dos monumentos nenhum tipo de legenda descrevendo e explicando as divindades representadas, que, na maior parte dos casos, são conhecidas somente pela população local.

Apesar da ideia de percurso e de evolução temporal que a Rota tenta sugerir, a ordem de aparição das estátuas é aleatória. As diversas esculturas, representando os vodus dos reis do Daomé que lideraram as guerras contra os estados vizinhos, durante as quais os cativos eram capturados, e que, também, participaram ativamente do comércio de escravos, não respeitam uma ordem cronológica. Partindo da Praça Chacha, encontra-se a primeira estátua, tendo como referência a iconografia da família real (Imagem 1). A escultura representa um pássaro, um dos símbolos do rei Kpengla (1774-1789), filho de Tegbessou e Nan Cai. Kpengla fez várias campanhas militares provocando a consolidação do domínio sobre o reino de Ajudá. Tendo conquistado várias cidades da costa, o rei também contribuiu no desenvolvimento do comércio de escravos. ${ }^{23}$

Um pouco mais longe, uma outra escultura representa Ganyé Hessou (1600-1625), que aparece na forma de um pássaro gangnihessou macho e de um tambor. Uma das versões da tradição conta que Ganyé Hessou, juntamente com seu irmão Dakodonu (1625-1650), ${ }^{24}$ teria lançado as bases do futuro reino do Daomé. O pássaro e o tambor são associados ao adágio de Ganyé Hessou: "Eu sou o maior pássaro e o mais forte tambor. Ninguém pode impedir o pássaro de cantar, ninguém pode impedir o tambor de tocar". Na sequência do caminho, encontra-se a estátua de um leão (Imagem 2), símbolo do rei Glèlè (1858-1889), filho do rei Guezo e Na Zognidi, às vezes associado à $\mathrm{Gu}$, divindade da metalurgia e da guerra. Glélé foi um dos reis que resistiu ao fim do comércio atlântico de escravos. Depois da morte de seu pai, ele afirmou publicamente sua decisão de prosseguir produzindo cativos e sustentando o comércio de escravos. Tendo sido rei durante o período final do tráfico atlântico, Glèlè mantinha uma relação conflitante com os mercadores da cidade de Ajudá que tinham suas mercadorias e

22 BLIER, S. P. African vodu: art, psychology, and power, p.95.

23 PIQUÉ, F. e RAINER, L. Wall sculptures of Abomey. London: The J. Paul Getty Trust Thames and Hudson, 1999, p.29 e LAW, R. Ouidah: the social history of a West African slaving "port", 1727-1892, p.64-65.

24 LAW, R. The Slave Coast of West Africa 1550-1750: the impact of the Atlantic Slave Trade on an African Society. Clarendon Press, 1991, p.261. 
Imagem 1: Símbolo do rei Kpengla, Cyprien

Tokoudagba, escultura em cimento, foto Ana Lúcia Araujo, Ajudá, Benim, 2005.



Imagem 2:

Símbolo do rei Glèlè, Cyprien Tokoudagba, escultura em cimento, foto Ana Lúcia Araujo, Ajudá, Benim, 2005

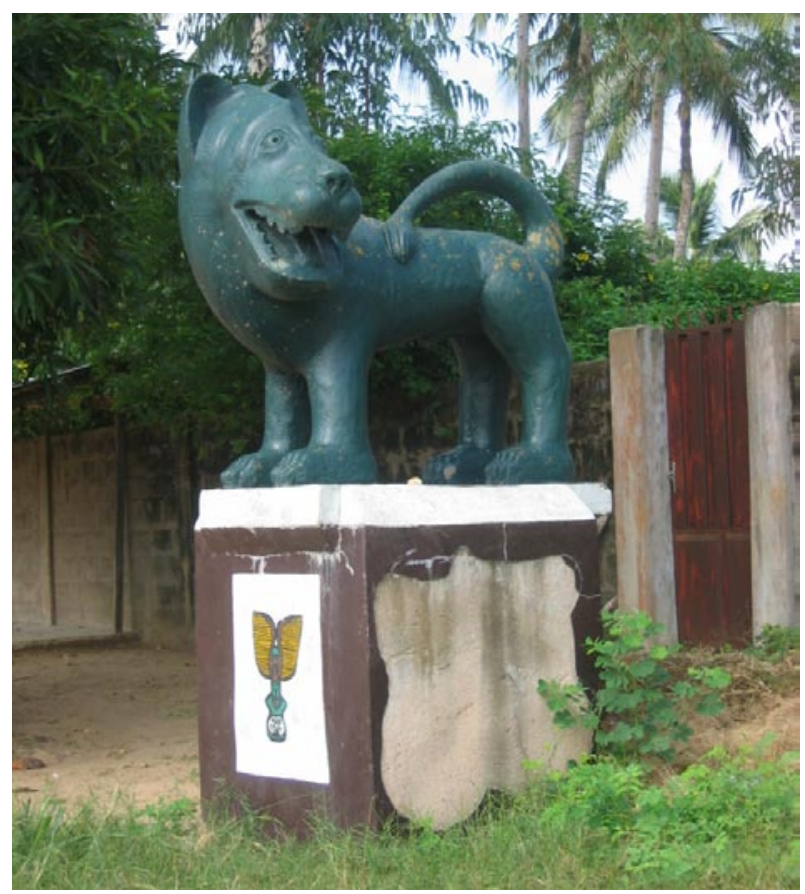




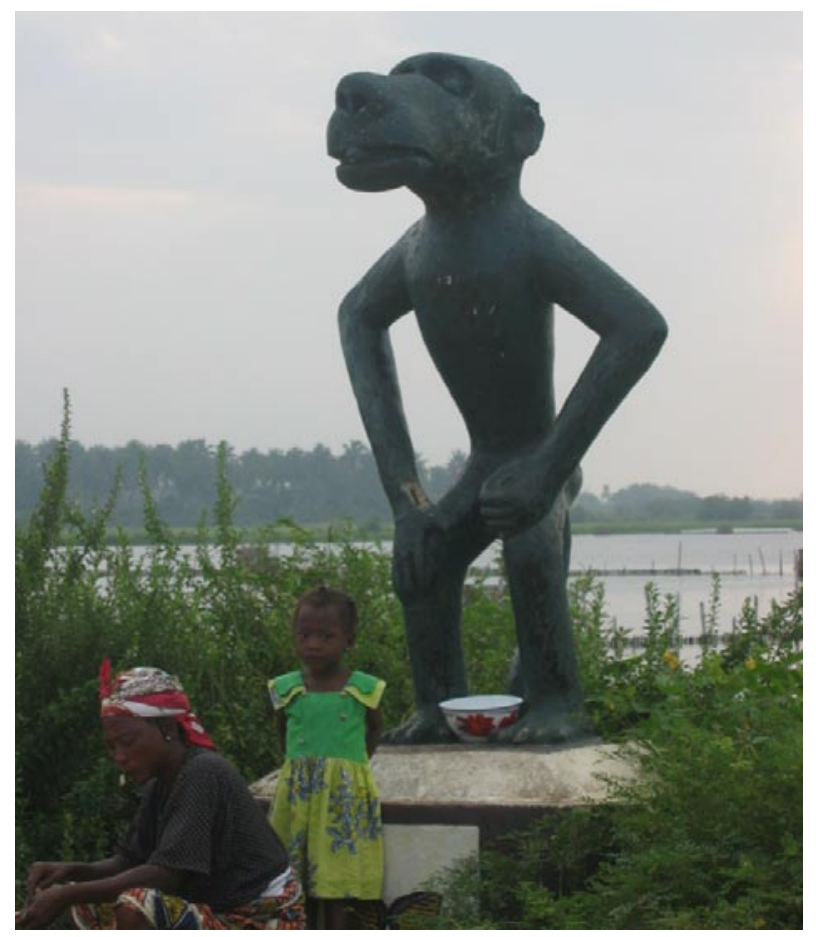

Imagem 3: Símbolo do rei Guezo, Cyprien Tokoudagba, escultura em cimento, foto Ana Lúcia Araujo, Ajudá, Benim, 2005.

seus bens apreendidos pelo rei. ${ }^{25} \mathrm{Um}$ pouco mais longe, outra estátua representa Dan Aïdohuedo, a serpente que come seu próprio rabo, formando um arcoíris. Dan Aïdohuedo é ligada ao rei Guezo, que tinha se comparado a Deus. Se a imagem da serpente leva à ideia de poder real intemporal e à de universalidade, ${ }^{26}$ ela também é relacionada com a riqueza representada pelas contas akori. ${ }^{27}$ Dotadas de um grande valor simbólico, essas contas já eram utilizadas durante o século XVI nas trocas comerciais que tinham lugar nas costas da África Ocidental e, segundo a crença, elas eram derivadas dos excrementos da serpente.

Uma outra escultura representando um babuíno é uma imagem ambígua (Imagem 3). Ela faz alusão a um episódio que teve lugar durante o reino de Adandozan (1797-1818). Cansado de pagar elevados tributos ao reino de Oyo, ${ }^{28}$ o rei daomeano enviou ao rei do estado iorubá, um guardassol com um aplique representando um babuíno comendo vorazmente. Mesmo que

25 LAW, R. Ouidah: the social history of a West African slaving "port", 1727-1892, p.248-249.

26 PIQUÉ, F. e RAINER, L. Wall sculptures of Abomey, p.75.

27 Ainda não existe um consenso em torno da origem das akori, "aggrey" ou "aggry". Segundo as descrições, as contas eram multicoloridas, mas principalmente da cor azul e sua composição (coral, pedra ou vidro) ainda hoje é discutida. DAVISON, C. C.; GIAUQUE, R. D.; CLARK, J. D. Two Chemical Groups of Dichroic Glass Beads from West Africa. Man, v.6, n.4, p.645-659, dezembro 1971.

28 O reino do Daomé era vassalo do reino de Oyo, Estado iorubá. Essa situação de submissão será revertida em 1818. 
a imagem revele a intenção de perpetuar a memória do rei Adandozan, a representação do macaco que come uma espiga é, hoje em dia, associada ao rei Guezo, visto que esse último contribuiu para a expansão do Daomé. Perto da praia, encontra-se a última escultura, fazendo referência a um rei daomeano. Ela representa um navio europeu, símbolo do rei Agaja (1716-1732), tido como irmão de Houegbadja (ou Wegbaja) ou como filho desse mesmo rei. ${ }^{29} \mathrm{Em}$ 1727, Agaja atacou e conquistou o reino de Ajudá, expandindo o território do reino que passou a ter acesso ao mar. Trata-se do primeiro rei daomeano a ter estabelecido relações comerciais com os europeus, tendo sido responsável pelo começo de um dos períodos mais ativos do comércio atlântico de escravos. Além disso, o rei formou o exército de amazonas, muIheres guerreiras, que se tornou uma marca distintiva do reino do Daomé.

Certos pontos da Rota indicam os lugares onde os escravos teriam passado antes de embarcarem nos navios. O lugar onde se acredita ter existido a Árvore do Esquecimento é marcado por uma escultura do artista Dominique Kouas representando uma Mami Wata, divindade das águas, bastante popular na África Ocidental e na África Central. As representações de Mami Wata fazem alusão à figura da sereia e tomam de empréstimo certos elementos do panteão hindu, entre os quais as três cabeças visíveis na deusa Dattatreya ${ }^{30} \mathrm{Na}$ base da estátua, pode-se ler:

\begin{abstract}
Nesse lugar se encontrava a "Árvore do Esquecimento". Os homens escravos deviam dar, em torno dela, nove voltas e as mulheres, sete voltas. Depois de darem essas voltas, os escravos deviam ficar amnésicos. Eles esqueciam completamente seu passado, suas origens e suas identidades culturais para se tornarem seres sem vontade de reagir ou de se rebelar. ${ }^{31}$
\end{abstract}

Esse monumento é um dos únicos a evocar a memória do cativo, que, em teoria, devia esquecer suas origens. Colocando em evidência uma representação do escravo como indivíduo sem vontade, sem identidade e sem capacidade de reagir diante de sua condição de cativo. O texto que acompanha o monumento vai contra grande parte dos estudos recentes, que mostram o escravo africano trazido para as Américas como organizador de rebeliões, como gente que lutou pela liberdade e que soube criar novos laços identitários e familiares.

Prosseguindo na estrada, chega-se à Zomaï, lugar onde os escravos eram reunidos. Na base do monumento, uma legenda explica o significado do sítio:

29 Sobre a ambigüidade relativa ao pai ou irmão do rei Agaja ver LAW, R. The Slave Coast of West Africa 1550-1750: the impact of the Atlantic slave trade on an African Society, p.264 e 266.

30 RUSH, D. Eternal Potential Chromolithographs in Voduland. African Arts, v.32, n.4, p.63, 1999

31 Tradução livre da seguinte legenda em francês: "En ce lieu se trouvait l'arbre de l'oubli. Les esclaves mâles devaient tourner autour de lui neuf fois, les femmes sept fois. Ces tours étant accomplis les esclaves étaient censés devenir amnésiques. Ils oubliaient complètement leur passé, leurs origines et leur identité culturelle, pour devenir des êtres sans volonté de réagir ou de se rebeller". 
Zomaï significa "que o fogo ou a luz não tem acesso". Na realidade, nesse lugar se encontrava um grande compartimento hermeticamente fechado, no qual os escravos ficavam enclausurados desde a chegada à Zounbodgi e do qual eles saíam apenas quando eram transferidos em direção à árvore do retorno. Este sequestro absoluto desorientava os escravos completamente e tornava extremamente difícil toda tentativa de fuga ou rebelião. A permanência nesse lugar condicionava os cativos para a vida futura de promiscuidade e obscuridade dos navios negreiros. ${ }^{32}$

No lugar onde a antiga construção se situava foram instaladas esculturas de Dominique Kouas e Cyprien Tokoudagaba. A escultura central concebida por Kouas representa os escravos de diferentes grupos étnicos, cujos rostos são marcados por escarificações.

Seguindo ainda o caminho da Rota dos Escravos se encontra o Memorial de Zoungbodji. Segundo a tradição, era nesse lugar em que os cativos eram marcados com ferro em brasa, procedimento que visava facilitar sua identificação junto a cada mercador de escravos. ${ }^{33}$ Ainda segundo a tradição local, muitos dos escravos que não sobreviveram ao cativeiro em Zomaï teriam sido enterrados nesse sítio. O memorial é uma construção em cimento fechada por um muro, medindo aproximadamente quinze metros quadrados. Duas esculturas de Cyprien Tokoudagba foram colocadas de cada lado da entrada do memorial. Elas representam um escravo e uma escrava de joelhos; atados e amordaçados (Imagem 4). No interior do memorial, na parte central e ao fundo, se encontra um imenso mosaico retangular, concebido por Fortuné Bandeira. Essa parte do memorial é uma das únicas que mostram quase somente formas abstratas em preto e vermelho sobre um fundo branco. Segundo o próprio artista, o preto representa os africanos acorrentados, enquanto a cor vermelha simboliza o sangue dos cativos. ${ }^{34}$ Do lado esquerdo do mosaico se encontram duas esculturas em metal reciclado, concebidas pelos irmãos Théodore e Calixte Dakpogan, representando dois rostos de cativos e um deles apresenta escarificações. À direita, uma escultura de Cyprien Tokoudagba representa um escravo de braços abertos, rompendo as cordas que prendiam seus punhos. Apesar do seu aspecto monumental, o memorial se encontra quase abandonado: seu portão é mantido trancado, a pintura das paredes está deteriorada e as esculturas estão completamente enferrujadas.

32 Tradução livre da seguinte legenda em francês: "Zomaï signifie 'que le feu ou la lumière ne s'y hasarde point'. En effet, en cet endroit, se trouvait une grande case hermétiquement close où les esclaves étaient enfermés dès leur arrivée à Zounbodgi et d'où ils ne sortaient que pour être transférés vers l'arbre du retour. Cette séquestration absolue désorientait totalement les esclaves et rendait extrêmement difficile toute tentative de fuite ou de rébellion. Ce séjour ici les conditionnait pour la vie de promiscuité et d'obscurité des cales des négriers".

33 Segundo Robin Law, esta hipótese é bem plausível. LAW, R. Ouidah: the social history of a West African slaving "port", 1727-1892, p.142.

34 RUSH, D. Contemporary Vodu of Ouidah, Benin. African Arts, v.34, n.4, p.43, 2001 


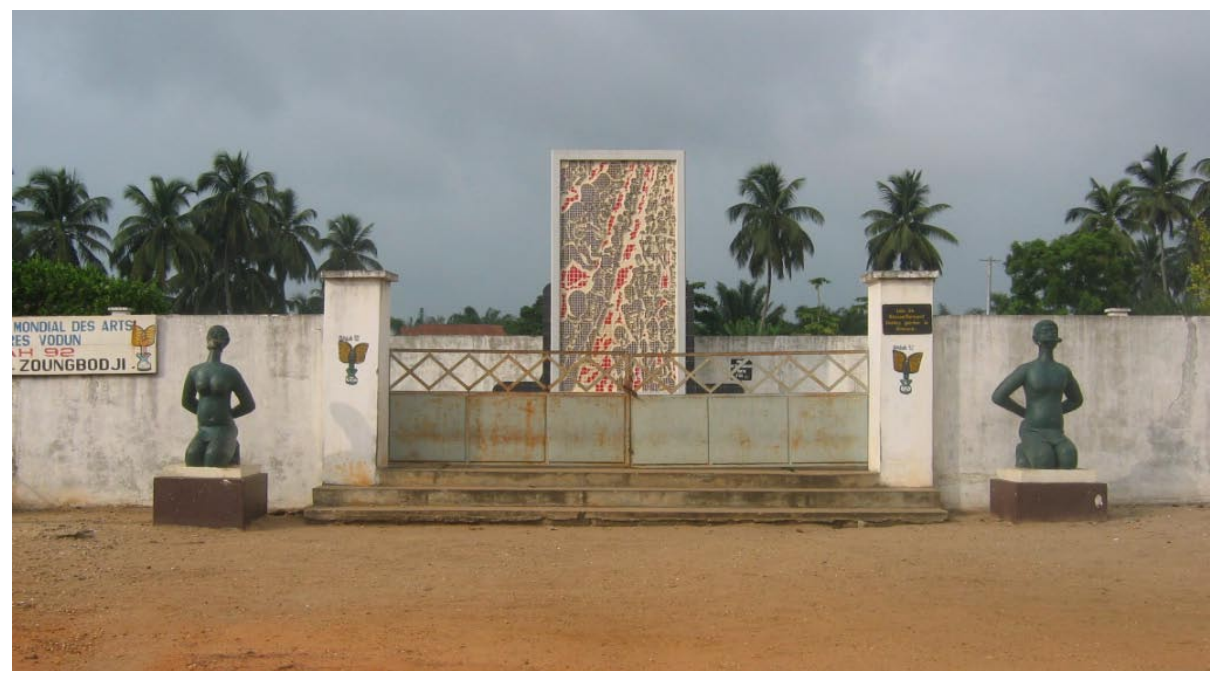

Imagem 4: Memorial Zoungbondji, Cyprien Tokoudagba, Fortuné Bandeira, Théodore Dakpogan e Calixte Dakpogan, foto Ana Lúcia Araujo, Ajudá, Benim, 2005.

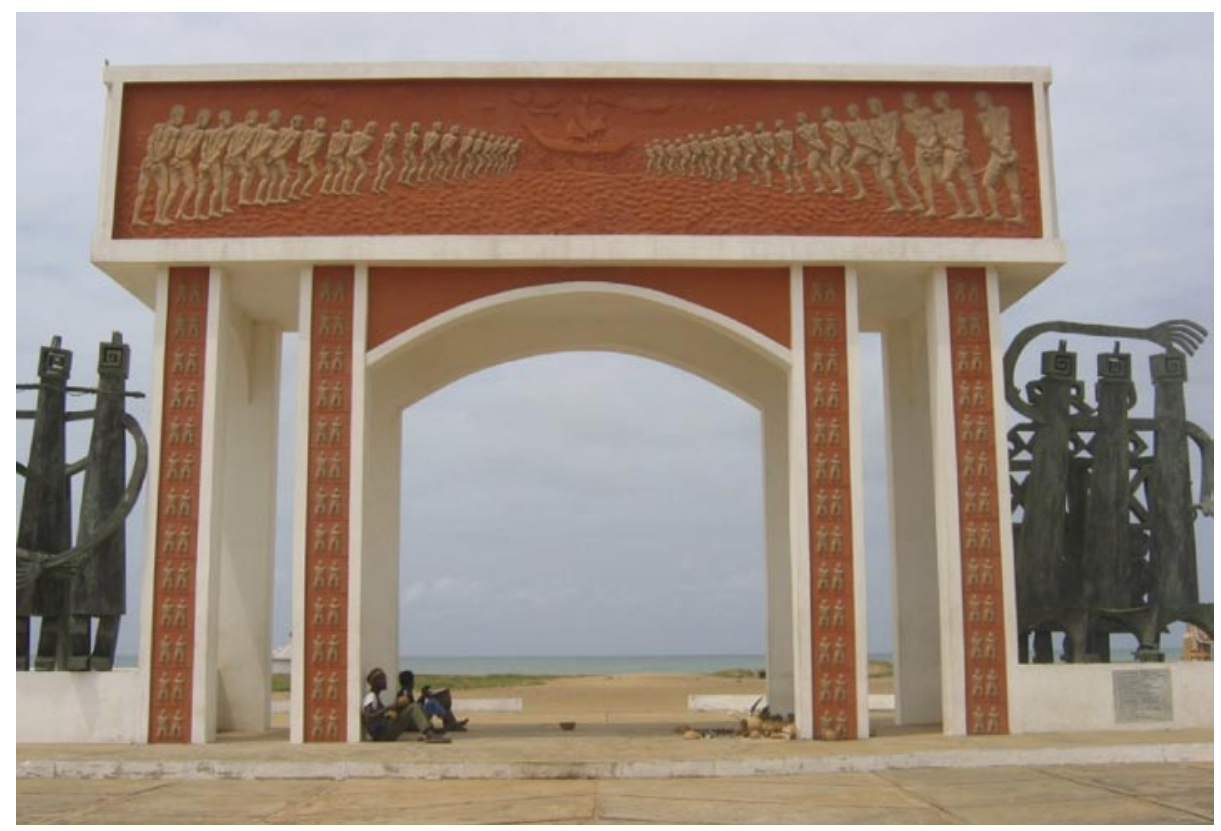

Imagem 5: Porta do não-retorno, Fortuné Bandeira, foto Ana Lúcia Araujo, Ajudá 2005.

O único monumento construído no quadro do projeto Rota do Escravo desenvolvido pela UNESCO é o Portão do não-retorno (Imagem 5). Situado na praia, no fim da Rota dos Escravos, o imponente portão foi inaugurado no mês de novembro de 1995. O monumento, concebido e decorado pelo 
artista beninense Fortuné Bandeira, segue uma estética monumental à moda soviética, simbolizando o lugar onde os cativos eram embarcados em direção às Américas ${ }^{35} \mathrm{O}$ portão tem como base uma grande plataforma de concreto, acima do nível do solo. O portal em forma de arco estabelece um ponto de transição entre a praia e o oceano, visível através do monumento. Ele é pintado de branco e de um vermelho terroso, tonalidade bastante utilizada nas paredes e nas fachadas das casas locais. As quatro colunas do monumento são decoradas com baixos-relevos ocres, representando casais de cativos nus e de joelho. Mais uma vez, essas representações enfatizam a imagem do escravo como bem móvel ou como vítima sem vontade própria. Esse mesmo tipo de imagem reaparece na parte superior do monumento, representando-se duas longas filas de escravos nus que caminham na praia em direção a um grande navio situado exatamente onde se encontra o ponto de fuga da composição. A repetição das imagens das silhuetas dos escravos dá ao conjunto a ideia de sequência e de movimento, dando uma impressão de deslocamento. A plataforma do monumento também é decorada com baixos-relevos simbolizando diversas divindades já mencionadas anteriormente, como Dan Aïdohuedo, Mami Wata e Gu. Além disso, na mesma plataforma encontram-se estátuas representando os Eguns, ${ }^{36}$ espíritos dos mortos, realizados pelo artista Yves Appolinaire Pédè. Além disso, quatro esculturas em ferro representando famílias de cativos se encontram em cada lado do portal. Concebidos pelo artista Dominique Kouas, estas representações são mais esquemáticas e geométricas e os rostos dos escravos parecem máscaras. Porém, a imagem que é ressaltada aqui não é mais aquela da vítima absoluta, mas sim a do resistente: os escravos que têm os braços levantados conseguiram arrebentar as correntes que Ihes mantinham presos.

No ano 2000, a unidade existente entre os monumentos da Rota dos Escravos e a Porta do não retorno foi afetada pela construção de um novo memorial, encomendado pela Igreja católica. Trata-se de um monumento em homenagem aos primeiros missionários católicos que chegaram ao Daomé durante a segunda metade do século XIX. Nesse contexto, a presença do novo memorial destoa dos outros monumentos que rememoram o vodu e a escravidão, pois a Igreja católica não somente legitimou a escravidão e o tráfico atlântico, como, também, sustentou a colonização francesa no Daomé, opondo-se, em muitos casos, às religiões autóctones. O novo

35 "The slaves and other commodities exported through Ouidah had therefore to be taken overland and across the lagoon to the beach, rather than being embarked directly into European ships". LAW, R. Ouidah: the social history of a West African slaving "port", 1727-1892, p.18.

36 "Geralmente trata-se de espíritos dos ancestrais familiares, cujos esforços em ajudar os vivos na verdade Ihes prejudica, porque o mundo deles é invertido em relação ao nosso" (tradução livre do inglês). MATORY, J. L. Black Atlantic religion: tradition, transnationalism in the Afro-Brazilian candomble. Princeton: Princeton University Press, 2005, p.129. 
memorial interfere também no impacto visual da Porta do não-retorno, pois as dimensões e as cores são bastante parecidas.

Em 2004, um outro monumento chamado Porta do retorno foi construído perto da praia. O monumento faz parte de um projeto que também inclui um pequeno museu. O projeto é fruto de iniciativa da Organização Nãogovernamental PROMETRA (Organização pela Promoção das Medicinas Tradicionais). ${ }^{37} \mathrm{O}$ monumento da Porta do retorno é composto de uma placa de cimento, na qual foi recortado um mapa da África e, também, de três esculturas em bronze simbolizando a mãe África, que recebe de braços abertos os dois filhos que voltam à terra de seus ancestrais. Perto do monumento se encontra o Museu da Porta do Retorno. Diante da fachada da construção encontram-se duas outras esculturas em bronze, quase em tamanho natural, representando dois escravos que rompem as correntes que lhes prendiam. Mais uma vez, as esculturas concebidas pelo artista Benjamin Mafort valorizam a imagem do escravo resistente, capaz de lutar e de escapar da prisão imposta pelo cativeiro.

\section{De vítima à resistente}

No Benim, o fenômeno desordenado de promoção da memória da escravidão no espaço público alterou os objetivos iniciais dos projetos oficiais. A criação de museus, a construção de monumentos e memoriais e a organização de festivais criaram uma dinâmica que valorizou diversas representações do comércio atlântico de escravos e da escravidão, acentuando, assim, as memórias pluriais e conflituais. Provavelmente, devido à sua situação política relativamente estável, o Benim tornou-se um pólo de atração para a instalação de diversas organizações não-governamentais e para a realização de projetos desenvolvidos por membros da elite local, em cidades como Ajuda, tendo como público alvo a diáspora. A ideia de uma Rota dos Escravos, que busca reproduzir o percurso feito pelos cativos dentro do território do antigo reino do Daomé antes de embarcar em direção às Américas, enfatiza uma representação vitimizante e às vezes estereotipada do escravo. As imagens do escravo acorrentado, do escravo agachado, do escravo nu ou ainda das filas de escravos que se preparam para embarcar no navio negreiro, tal como são mostradas nos diferentes memoriais e monumentos de Ajudá, informam pouco sobre a complexidade da história da escravidão e do tráfico atlântico na região.

Em um primeiro nível, esse conjunto de monumentos constitui uma encenação cujo objetivo é emocionar a diáspora norte-americana, que tem recursos financeiros para fazer turismo em países estrangeiros. Estes

37 Prometra International (Organisation pour la Promotion de Médecines Traditionnelles) http://www.prometra.org/ 
turistas desejam "reexperimentar" a trajetória de seus ancestrais, mesmo se a maior parte dos descendentes dos cativos deportados da região do golfo do Benim se encontrem hoje em países como o Brasil, Cuba e Haiti. Apesar disso, existe um segundo nível de leitura do percurso sugerido, que escapa às iniciativas desenvolvidas pelos organismos oficiais e que, talvez, seja menos compreensível para o turista. As estátuas concebidas por Cyprien Tokoudagaba e os templos existentes na estrada entre o centro da cidade e a praia conseguem posicionar o visitante no cruzamento de diferentes memórias e diferentes histórias da escravidão. Pouco a pouco, a vitimização dá lugar à afirmação cultural que valoriza a arte, as religiões e as culturas africanas que resultaram do comércio atlântico, abrindo, assim, a porta a novas representações do escravo resistente, capaz de ultrapassar a condição de simples vítima para tornar-se mestre de si. 